\title{
PO SLEDEH ANTIFONALA LJUBLJANSKE STOLNICE
}

\author{
JURIJ SNOJ \\ Znanstvenoraziskovalni center SAZU
}

Izvleček: Med v Ljubljani hranjenimi fragmenti koralnih rokopisov so ostanki dvodelnega antifonala in psalterja, ki ju je izdelala ista roka. Rokopisi, ki so jim ti fragmenti pripadali, so sledili oglejskemu obredu; nastali so $v$ drugi pol. 15. stol. (ali celo na začetku 16. stol.), se pravi v času, ko je kapitelj novoustanovljene ljubljanske škofije (1461) začel opravljati koralno bogoslužje. Uničeni so bili v drugi pol. 17. stol., ko je bil v ljubljanski škofiji stari oglejski obred zamenjan z rimskim. $Z$ ozirom na to je zelo verjetno, da predstavljajo prvi antifonal in psalter ljubljanske škofije.

Ključne besede: koral, oglejski obred, ljubljanska škofija

\begin{abstract}
The fragments of plainchant manuscripts kept in the Ljubljana archives include the remnants of a two-volume antiphoner and a psalter, written in the same hand. The manuscripts these fragments belonged to followed the rite of Aquileia and they were compiled in the second half of the fifteenth century (or even in the first decades of the sixteenth century); that is, in the period when the chapter of the newly-founded diocese of Ljubljana (1461) began performing plainchant liturgy. The manuscripts were destroyed in the second half of the seventeenth century, when the Roman rite replaced the Aquileian rite in the Ljubljana diocese. Thus it seems very likely that they are remnants of the first antiphoner and psalter of the Ljubljana cathedral.
\end{abstract}

Keywords: plainchant, Aquileian rite, Ljubljana diocese

Leta 1461 je bila v Ljubljani, glavnem mestu vojvodine Kranjske, ustanovljena škofija. ${ }^{1}$ 6. decembra tega leta, na god zavetnika nove stolnice, sv. Nikolaja, je cesar Friderik III. v Gradcu izdal ustrezno ustanovno listino. Devet mesecev kasneje, 6. septembra 1462, je v italijanski Pienzi papež Pij II. (Enej Silvij Piccolomini) izdal bulo Romanus Pontifex, s

1 O okoliščinah, ki so vodile do ustanovitve, gl. razpravi: Žnidaršič Golec, Duhovniki kranjskega dela ljubljanske škofije do tridentinskega koncila, 23-36; eadem, „Vzroki in okoliščine ustanovitve ljubljanske škofije ter oblikovanje njenega ozemlja«, 7-16. 
katero je ponovil določbe cesarjeve listine, poleg tega pa dodal še nekaj drugih določil. ${ }^{2}$ S cesarsko ustanovno listino je bilo določeno, da postane cerkev sv. Nikolaja v Ljubljani, dotlej podružnica cerkve sv. Petra (takrat že zunaj ljubljanskega obzidja), sedež nove škofije; ob njej se ustanavlja tudi kapitelj, ki naj vključuje prošta (praepositus), dekana (decanus), deset kanonikov (canonicus) in štiri vikarje (vicarius).

Prva in najpomembnejša naloga vsakega kapitlja je bila opravljanje bogoslužja, in to je tudi izrecno navedeno $\mathrm{v}$ cesarski ustanovni listini:

Volentes ut idem episcopus, praepositus, decanus, canonici, una cum vicariis perpetuis futuris temporibus, iuxta ordinationes, et statuta per eos edenda, et statuenda, officium quinque horarum canonicarum, videlicet, primam, tertiam, sextam, nonam, et completorium, in dicta ecclesia sancti Nicolai, quotidie decantent, ac matutinas per praefatos vicarios, et aliquem seu aliquos ex eis, prout ipsi super hoc statuent. Necnon vesperas per scolares eiusdem oppidi decantari procurent. Ad haec qualibet die duo officia, unum de Beata Virgine, secundum de tempore aut festo, prout occurret, per ipsos canonicos, et vicarios, et a scolaribus ad finem cum sequentiis, simbolo praefatione et oratione dominica, plenarie iuxta cuiuslibet temporis exigentiam et rubricam Aquileiensem decantentur. Dicti etiam episcopus, praepositus, decanus, et capitulum in qualibet angaria anni, in refrigerium nostrae, ac nostrorum praedecessorum, haeredum, et successorum, ac omnium fidelium defunctorum animarum, vigilias mortuorum, una cum officio pro defunctis, ultra praedicta duo officia, decantare debebunt. Fiantque alii cantus, lectiones, et processiones, cum caeteris ecclesiasticis ceremoniis, quemadmodum, haec omnia iuxta ordinem rubricae, seu breviarii Aquileiensis ecclesiae, et statuta, de quibus infra fit mentio, pro quolibet tempore anni fuerint observanda. Si vero episcopus, praepositus, decanus, canonici, et vicarii dicti, ultra praescriptas missas, et officia etiam alias et plures missas celebrare voluerint, id suis conscientiis et voluntatibus relinquimus. Ita quod eos praesentis fundationis nostrae vigore ad officia plura quam superius est expressum, non intendimus obligare.

Hočemo, da škof, prošt, dekan, kanoniki skupaj z vikarji vse večne prihodnje čase v omenjeni cerkvi sv. Nikolaja vsak dan odpojejo - skladno z odločbami in statuti, ki jih bodo izdali in potrdili, petero kanoničnih ur, namreč prvo, tretjo, šesto, deveto in sklepnice; omenjeni vikarji in eden ali več kanonikov, kot bodo o tej stvari odločili sami, naj odpojejo tudi jutranjice; prav tako naj poskrbijo, da bodo mestni učenci odpeli večernice. Poleg tega naj kanoniki, vikarji in učenci vsak dan odpojejo dve maši, in sicer v celoti, s sekvencami, simbolom, prefacijo in Gospodovo molitvijo: prvo Blažene Device in drugo temporalno ali svetniško, kot bo naneslo; odpeti naj bosta popolno, kot zahteva kateri koli letni čas, in po oglejskem obredu. Omenjeni škof, prošt, dekan in kapitelj bodo morali v dobro naše duše, duš naših predhodnikov, dedičev, naslednikov in v dobro vseh vernih duš vsake kvatre odpeti tudi oficij za umrle skupaj z mašo za umrle - poleg omenjenih dveh maš. Drugi spevi, berila, procesije z nadaljnjimi cerkvenimi obredi, vse to naj poteka po redu oz. brevirju oglejske cerkve in po določilih, ki se omenjajo spodaj, upoštevajoč čas leta, ko se opravljajo. Če pa bi imenovani škof, prošt, dekan, kanoniki in vikarji poleg predpisanih maš in oficija želeli obhajati več drugih maš, prepuščamo to njihovi vesti in odločitvi. $Z$ močjo te naše ustanove jih tako ne nameravamo obvezati $\mathrm{Z}$ več opravili, kot je navedeno zgoraj. ${ }^{3}$

2 Objava listin: Žnidaršič Golec, Duhovniki kranjskega dela ljubljanske škofije do tridentinskega koncila, 307-313, 314-317.

3 Prevod J. Snoj. 
Kot izhaja iz besedila, naj bi se v stolnici vsak dan opravil celotni oficij in dve maši (gl. preglednico 1). Vsakodnevni oficijski obredi so natančno določeni: kanonične ure, kot so imenovane (prva, tretja, šesta, deveta ter sklepnice), naj opravijo kanoniki; jutranjice vikarji z morebitno udeležbo enega ali nekaj kanonikov po njihovi lastni odločitvi; večernice so poverjene učencem. ${ }^{4} \mathrm{~S}$ tem imamo v listini vse obrede dnevnega oficijskega ciklusa z izjemo hvalnic (laudes). Izpust bi si lahko razlagali s tem, da so se hvalnice običajno opravljale neposredno po jutranjicah; navedba jutranjic bi tako mogla zaobjemati tudi hvalnice.

Preglednica 1: Liturgične določbe ustanovne listine ljubljanske škofije

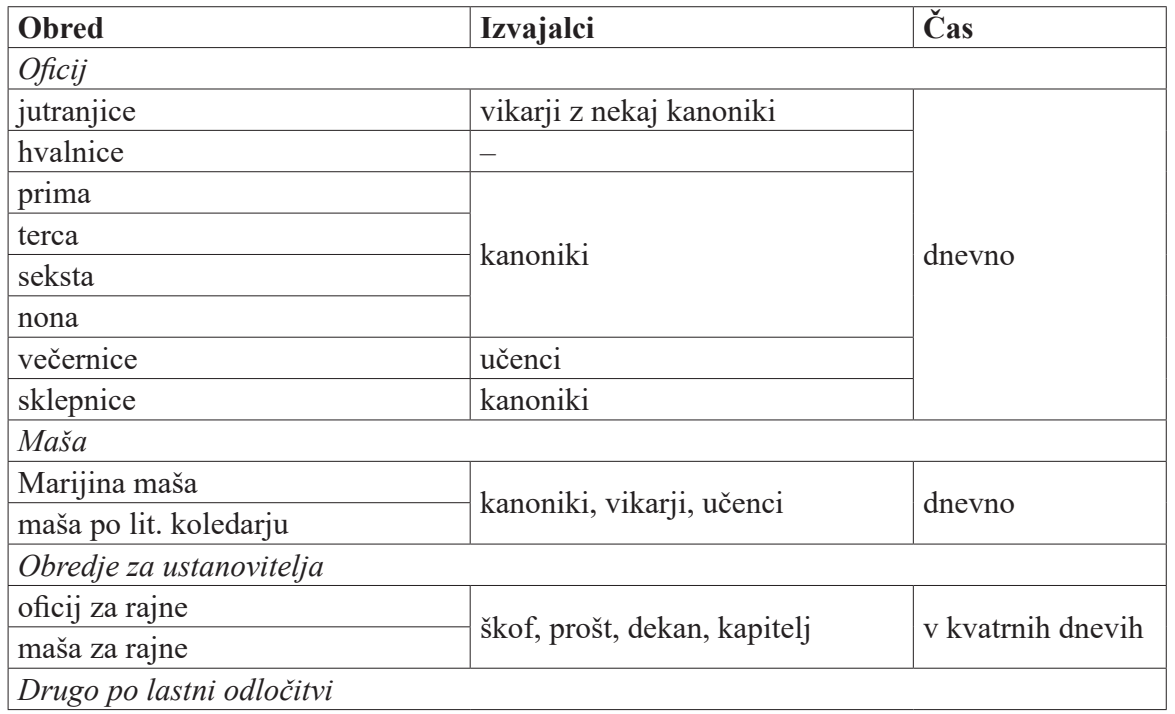

Sledijo določbe glede maše. Maša se v listini označuje kot »officium«, kar zavaja k domnevi, da je s tem mišljeno oficijsko obredje, še zlasti, ker se v listini malo poprej oficijske kanonične ure označujejo tudi kot »officium«; vendar ima izraz v listini splošni pomen: 'dolžnost', 'opravilo', in se ne nanaša na oficij kot oficijsko bogoslužje. Da je tako, je razvidno iz določila, naj »oficij« obsega sekvenco, veroizpoved, prefacijo in Gospodovo molitev (Očenaš), kar vse so deli maše. Tudi v nadaljevanju listinskega besedila najdemo formulacijo »poleg predpisanih maš in oficija«, kar še dodatno potrjuje, da je sestavljavec pogodbe z izrazom »duo officia«, 'dva oficija', imel v mislih dve maši. Prva od teh naj bo posvečena Mariji, druga pa naj bo ali temporalna ali praznična, kar se smiselno razume kot maša po običajnem liturgičnem koledarju, v katerem se menjujejo temporalni in sanktoralni dnevi in prazniki.

Nadalje je določeno, naj vsi: škof, prošt, dekan, kanoniki in vikarji ob kvatrnih dnevih, kar je bilo štirikrat na leto, opravijo »vigilije« in »oficij« za umrle, in sicer v dobro ustanoviteljeve duše kot tudi duš njegovih prednikov in naslednikov. Izraza »vigilije « in »oficij« nista povsem nedvoumna; »vigilije« je smiselno mogoče razumeti kot oficij ali

4 Kot je znano, je bila šola pri sv. Nikolaju leta 1418 obnovljena; omenjena je še v nekaterih drugih virih iz druge pol. 15. stol. Grabnar, »Pričevanja o glasbi v šolskih ustanovah«, 411-413. 
del oficija za rajne, predvsem jutranjice, ${ }^{5}$ oficij pa kot mašo za rajne (tj. Requiem). Slednjič je v listini dopuščeno, da se po prosti presoji lahko opravljajo še druge maše in oficiji.

Dvoje listinskih določil velja v zvezi z vprašanji tega sestavka posebej izpostaviti: 1. Glagol, s katerim se označuje, kaj naj se z vsemi navedenimi liturgičnimi opravili dogaja, je zmeraj »decantare«, 'peti', 'odpeti', in nikdar »legere« 'brati'. Vse predpisano naj se torej poje. 2. Vsa liturgična opravila naj sledijo obredu oglejske cerkve. Če smo zelo natančni, je oglejski obred predpisan za obe maši, in proti koncu odstavka, ki govori o bogoslužju, je navedeno, naj »vse to« poteka po oglejskih določilih oz. po oglejskem brevirju (ki je vseboval le oficijsko liturgijo), vendar je smisel določila nedvoumen.

Izdaja listine sama po sebi še ne pomeni, da se je vse, kar je zapisano v njej, tudi uresničevalo. Nenavadno je, da bula Romanus Pontifex, ki je svojevrstni vrhunec sintaktične nabreklosti, liturgičnih dolžnosti novega kapitlja sploh ne omenja. Kljub temu smemo domnevati, da se je v ljubljanski stolnici že v drugi pol. 15. stol. začelo opravljati skupinsko peto bogoslužje po oglejskem obredu. Iz prvega statuta ljubljanskega kapitlja iz leta 1519 je vsekakor razvidno, da so se njegovi člani shajali k obredju. ${ }^{6} \mathrm{Za}$ to so bili potrebni ustrezni koralni rokopisi ali tiski: za oficijsko bogoslužje antifonal, psalter in lekcionar, za mašno misal in gradual; škof je za svoje obrede potreboval pontifikal. Profesor Marijan Smolik je uspel odkriti ostanke prvega ljubljanskega pontifikala, ${ }^{7}$ medtem ko drugi potrebni liturgični rokopisi ali tiski, ki bi se mogli uporabljati v predtridentinskem obdobju ljubljanske škofije, niso znani. Postavlja se vprašanje: Ali je med številnimi fragmenti uničenih srednjeveških liturgičnih rokopisov, ki so se ohranili v Ljubljani, možno prepoznati preostanke rokopisov ljubljanskega kapitlja?

\section{II}

Kot je znano, so se liturgični rokopisi, ki so prišli iz rabe, v preteklosti zelo pogosto uničevali, njihovi pergamentni foliji pa uporabljali v razne druge namene, med drugim kot knjigoveško gradivo. Val uničevanja starih liturgičnih rokopisov je bil močen zlasti v obdobju po tridentinskem koncilu, ki je skušal prenoviti liturgijo in odstraniti iz nje medievalizme, ki niso bili v duhu časa. Tudi v slovenskih knjižnicah in arhivih se je ohranilo več sto posamičnih folijev iz uničenih srednjeveških koralnih rokopisov, ki so preživeli skoraj izključno kot zalepki v vezavah raznih mlajših tiskov, rokopisov in arhivalij. ${ }^{8}$ Stevilni tovrstni foliji nimajo para in so edini preostanki rokopisov, ki so jim nekdaj pripadali, se pravi, da se je od rokopisov, ki so jim nekdaj pripadali, ohranil le po en list. V več primerih pa se je iz istega uničenega rokopisa ohranilo več folijev, ki so zdaj

5 V sočasnih nemških listinah se srečuje izraz »vigili«, ki najverjetneje označuje jutranjice in morda še hvalnice oficija za umrle. Snoj, »Petje v srednjeveških obrednih ustanovah«, 100-101.

6 Statut je objavljen v delu: Žnidaršič Golec, Duhovniki kranjskega dela ljubljanske škofije do tridentinskega koncila, 327-333.

7 Smolik, »Pontifikal prvih ljubljanskih škofov«.

8 O fragmentarno ohranjenem koralnem rokopisju gl. Snoj, »Gregorijanski koral in liturgično enoglasje $\ll, 75-81$. 
v vezavah na različnih mestih hranjenih knjig. Del tovrstnega srednjeveškega rokopisja skoraj gotovo nima zveze s slovenskim ozemljem: v primerih, ko se je iz nekega rokopisa ohranil en sam folij, in sicer na platnicah v kakem oddaljenem mestu izdanega tiska, je verjetno, da je prispel na svojo sedanjo lokacijo obenem s tiskom, v zvezi s katerim se je ohranil. Ko pa imamo večje število listov iz istega rokopisa, ohranjenih v vezavah knjig in arhivalij, ki so bile vezane tu, na Slovenskem, je očitno, da je bil rokopis, ki so mu nekdaj pripadali, v času svojega uničenja, morda pa tudi v času svoje uporabe, tu.

$\mathrm{V}$ tem zanimivem gradivu vzbudi pozornost 54 folijev večjega formata, pisanih nedvomno $\mathrm{z}$ isto besedilno in isto notatorsko roko. Vsi so se ohranili v vezavah raznih ljubljanskih arhivalij in se zato hranijo na različnih mestih: v Zgodovinskem arhivu Ljubljana, v Nadškofijskem arhivu Ljubljana, v Semeniški knjižnici v Ljubljani in v Arhivu Republike Slovenije. Natančnejši pogled pokaže, da po formatu niso povsem enaki in da se razlikujejo tudi po oblikovanju pisnega dela strani, se pravi po tem, kako je zapis na njihovih straneh razporejen. Trije različni formati in tri različne razporeditve pisnega dela strani se ujemajo s tremi različnimi vsebinami: spremenljivi peti deli oficijske liturgije za prvi del liturgičnega leta, spremenljivi peti deli oficijske liturgije za drugi del liturgičnega leta, psalter s himnarjem. Ohranjeni foliji pripadajo torej antifonalu v dveh delih in psalterju, ki ju je kompiliral isti pisar in sta bila očitno zamišljena kot komplet, ki naj bi se uporabljal na istem mestu. Oglejmo si osnovne kodikološke značilnosti treh rokopisov.

Antifonal I. ${ }^{9}$ Ohranjeno je 35 folijev: 30 celih in 5 nepopolnih. ${ }^{10}$ Njihov format je 46,4 x 34,1 cm, format njihovega zrcala 33,7 x 25,4 cm. Na vsaki strani je 7 vrst; višina štirivrstnega črtovja meri $2,4 \mathrm{~cm}$. Rekonstrukcija ohranjenih folijev v glavnem ni bila težavna. Kljub temu, da rubrični naslovi dni in oficijskih obredov niso zmeraj ohranjeni, na osnovi primerjav ni bilo težko ugotoviti liturgične pripadnosti ohranjene vsebine. ${ }^{11}$

9 Vsi trije rokopisi so rekonstruirani v prilogi. Pravopis rubrik je podan diplomatsko, vendar so krajšave razrešene. Podani incipiti spevov in drugih besedil so pravopisno posodobljeni in poenoteni. Znak * ob koncu incipita pomeni, da je spev ali besedilo v rokopisu navedeno le z incipitom. Dodane rubrične oznake so v oglatih oklepajih; tako tudi nekaj drugih opomb. Ne glede na to, ali je v rokopisu navedena ali ne, je v posebni koloni (prvi levo) določena zvrst speva oz. besedila. Okrajšave pomenijo: An. = antifona; An.M = antifona h kantiku Magnificat; An.B = antifona $\mathrm{h}$ kantiku Benedictus; Ps. = psalm; Ve. = verzet; Re. = responzorij; V. = responzorijski verz; Pr. = proza; Reb. = kratki responzorij; Hy. = himnus.

${ }^{10}$ Tisti del fragmenta, ki se hrani v ZAL, je prvi opisal Janez Höfler. Höfler, »Gorenjski prispevki«, 91, 97.

${ }^{11}$ Rekonstrukcijska razporeditev folijev je ostala $\mathrm{v}$ dveh primerih nekoliko nejasna: 1. Vsebina fol. 15 je premalo izrecna, da bi jo bilo mogoče natančno določiti; pripadala bi lahko tudi kakemu drugemu dnevu velikonočnega časa, npr. beli nedelji. V tem primeru bi moral biti fol. 15 prestavljen za zdajšnji folij 16. 2. Fol. 32 in 33 , ki sta $v$ resnici le podolžna odrezka (in ne popolna folija), sta se ohranila v vezavi dveh zvezkov drobnih tiskov, zlasti raznih libretov, ki jih je zbral in dal vezati F. J. Thallmainer. Zvezka imata povsem enako vezavo in skoraj gotovo sta bila vezana istočasno. To govori v prid domnevi, da sta bila fol. 32 in $33 \mathrm{v}$ rokopisu, ki sta mu pripadala, sosednja, ali pa sta morda celo izrezka iz istega folija. Knjigovezec, ki je zvezka vezal istočasno, je razrezal isti pergamentni folij ali pa izrezal iz uničevanega rokopisa odrezka dveh zaporednih folijev. Vsebina fol. 33 se nedvomno nadaljuje na fol. 34, kar vodi k domnevi, da je na fol. 31-34 isti oficij. O njem gl. nadaljevanje. 
Ohranjeni so iztržki iz adventnega, božičnega in velikonočnega časa ter iztržki iz pomladanskega sanktorala.

Antifonal II. Ohranjeno je 6 folijev: 2 cela in 4 nepopolni. Fol. 3 in 4, oba nepopolna, tvorita dvojni folij. Format folijev je 44,1 x 33,2 cm, format njihovega zrcala 34,8 x 24,4 $\mathrm{cm}$. Na vsaki strani je 8 vrst; višina štirivrstnega črtovja meri $2,45 \mathrm{~cm}$. Da pripadata temu rokopisu tudi fol. 5 in 6 , ki sta nepopolna (in tako ni mogoče ugotoviti njunega prvotnega formata), je razvidno iz njunih drugih mer (razmaka med vrsticami). Ohranjeni so iztržki iz poletnega in jesenskega sanktorala.

Psalter. Ohranjeno je 14 folijev: 8 celih in 6 nepopolnih. Foliji 9 in 14, 10 in 13 ter 11 in 12 tvorijo tri dvojne folije. Format folijev je 33,5 x $27,7 \mathrm{~cm}$, format njihovega zrcala 28,7 x $21 \mathrm{~cm}$. Zaradi vsebine, ki sestoji predvsem iz besedil psalmov, število vrst z glasbenim zapisom ni enotno. Na nekaterih straneh glasbenega zapisa sploh ni. Višina štirivrstnega črtovja meri $2,05 \mathrm{~cm}$. Ohranjeni so iztržki iz tedenskega cikla psalmov, in sicer za sredo in četrtek, ter del kvadragezimalnega in velikonočnega himnarja.

Kot je razvidno iz zgornje predstavitve, sta prvi in drugi del antifonala kodikološko precej podobna; glavna razlika med njima je ta, da ima drugi del na vsaki strani eno vrstico več, zaradi česar je zapis ob le malenkostno višjem zrcalu nekoliko bolj stisnjen. Psalter ima manjši format in zato tudi nekoliko manjšo višino črtovja.

Notacija rokopisa je pozna gotska notacija, in sicer tip, ki se v stari Stäbleinovi sistematiki označuje kot metenska notacija tretjega obdobja. ${ }^{12}$ (V sodobni medievistični literaturi nima enotnega poimenovanja.) Ta način zapisovanja korala in drugega nemenzuriranega enoglasja je bil v poznem srednjem veku razširjen zlasti v južnonemškem vplivnem prostoru, kamor so spadale tudi slovenske dežele. Velika večina na Slovenskem hranjenih glasbenih zapisov iz 15. stol. je v natančno tem tipu pisave, tako tudi Antifonal iz Kranja. Obravnavani rokopisi so pisani v lepo izdelani glasbeni pisavi, ki je sicer takoj razpoznavna in značilna, vendar pa močno formalizirana (shematizirana) in zato tudi neosebna. Z ozirom na stopnjo formaliziranja bi težko nastali pred sredino 15. stol., lahko pa bi izhajali tudi iz 16. stol. Kot je bilo omenjeno, sta jih spisala isti pisar in isti notator, kar pomeni, da so bili izdelani v istem skriptoriju, v istem času in najverjetneje tudi za isto skupnost. V obdobju, iz katerega izhajajo, je bilo glasbeno pismenstvo toliko razširjeno, skriptorijev tako veliko število, da bi bil poskus, določiti mesto njihovega nastanka, brez zelo širokega primerjalnega gradiva segljaj v negotovo.

Posvetimo se v nadaljevanju liturgičnovsebinskim značilnostim ljubljanskih rokopisov.

\section{III}

Oficijsko liturgijo leta bi si bilo mogoče predstavljati kot strukturo z ogromnim številom funkcijsko določenih mest, ki so bila $\mathrm{v}$ različnih liturgičnih izročilih zapolnjena $\mathrm{z}$ istimi ali različnimi spevi in besedili. Tak način gledanja bi omogočal eksaktne primerjave posameznih izročil in eksaktne določitve liturgične pripadnosti posameznih rokopisov. Vendar pa srednjeveška liturgična izročila in liturgične prakse posameznih cerkva niso

${ }^{12}$ Stäblein, Schriftbild der einstimmigen Musik, 67-68, 202-203. 
bile določene v vseh detajlih. Kaj je bil oglejski obred, ki ga omenja ustanovitvena listina ljubljanske škofije, je razvidno iz rokopisov, ki so bili v rabi v oglejskih središčih, kot sta bila Oglej in Čedad, in iz zgodnjih oglejskih liturgičnih tiskov. A ti rokopisi niso povsem enaki; na njihovi osnovi ni mogoče izdelati sheme z dokončnim (čeprav še tako velikim) številom funkcijsko določenih mest, niti ne bi bilo mogoče določiti, katera besedila in spevi natančno in nespremenljivo zapolnjujejo ta mesta. Po drugi strani je določevanje liturgične pripadnosti težavno zaradi koralnih rokopisov samih. Vsak od njih vsebuje le določeni izsek spevov, ki ga je treba z namenom, da bi se dokončno razumel in ovrednotil, kombinirati z vsebino enega ali celo več drugih rokopisov. A to početje se večkrat konča v dvoumju.

Ta splošna opažanja ne pomenijo, da oglejskega obreda ni mogoče prepoznati; pomenijo le, da ostaja v posameznih detajlih nejasen in nedoločljiv, zlasti pa, da metoda ugotavljanja liturgične pripadnosti danega rokopisa po svoji naravi ne more biti eksaktna. V ohlapnejših potezah so značilnosti oglejskega obreda dobro prepoznavne; videti jih je mogoče tako v vsebinsko sicer manj pomembnem specifičnem razporedu splošno poznanih spevov znotraj oficijev vsesplošno poznanih praznikov in dni, predvsem pa $\mathrm{v}$ obstoju specifičnih oglejskih oficijev, še zlasti za tiste svetniške praznike, ki so bili bolj ali manj poznani le znotraj patriarhata.

Da bi si bilo mogoče ustvariti predstavo o liturgični pripadnosti obravnavanih rokopisov, je treba njihovo liturgično vsebino primerjati z nekaterimi drugimi liturgičnimi izročili. V prvi vrsti je potrebna primerjava z oglejskim obredom, ki jo je mogoče izpeljati na osnovi tiskanega oglejskega brevirja iz leta 1496 (v nadaljevanju BA) ${ }^{13}$ in posplošenega popisa oglejske oficijske liturgije, narejenega na osnovi najpomembnejših oglejskih rokopisov (v nadaljevanju A). ${ }^{14}$ Oglejskemu patriarhatu bližnja cerkvena pokrajina z lastno liturgično tradicijo je bila salzburška nadškofija; tako se zdi smiselno primerjati ljubljanske rokopise s tiskanim salzburškim brevirjem iz leta 1497 (v nadaljevanju BS) ${ }^{15}$ in posplošenim pregledom salzburške oficijske liturgije (v nadaljevanju $S$ ). ${ }^{16} \mathrm{~V}$ poznem srednjem veku se je močno širil rimski obred; s tem izrazom (ki v zgodovini liturgije in glasbe zaznamuje več različnih stvari) je mišljen obredni red, ki ga je za novi red manjših bratov v 13. stol. sestavil Haymo iz Favershama (v nadaljevanju R); ${ }^{17}$ ta red je že v 13. stol. sprejela rimska kurija, za tem pa številne druge cerkve; tudi na ozemlju oglejskega patriarhata ni bil nepoznan, saj ga srečamo npr. v rokopisih koprske stolnice. Tako zamišljena primerjava lahko pokaže, kaj je bilo v poznem srednjem veku splošno, kaj je skupno oglejskemu in salzburškemu izročilu (ne pa rimskemu) in kaj je bilo specifično oglejsko.

Iz primerjave temporalnega dela vidimo (gl. prilogo), ${ }^{18}$ da se ljubljanski rokopis z izjemo

${ }_{13}$ Breviarium Aquileiense.

${ }^{14}$ Gilányi, Kovács, Dobszay, Aquileia (Temporale).

${ }^{15}$ Breviarium Salzeburgense.

${ }^{16}$ Dobszay, Salzburg (Pars Temporalis); Fehér, Dobszay, Salzburg (Sanctorale).

${ }^{17}$ Haymov Ordo Breviarii je objavljen v delu: van Dijk, Sources of the Modern Roman Liturgy, 2:15-195.

${ }^{18}$ Primerjava v prilogi se omejuje le na prikaz tega, ali je v danem obredu spev na istem mestu ali ne. Znak * označuje, da je spev v danem obredu na istem mestu, znak - pomeni, da je na tistem mestu drugi spev, znak ? pa opozarja, da na vprašanje ni bilo mogoče dati zanesljivega odgovora. 
nekaj nejasnih mest povsem ujema z oglejskim obredom; več razlik se kaže v razmerju do salzburškega obreda, še več pa v razmerju do rimskega. Med drugim imajo nekateri responzoriji v rimskem obredu druge verze, kar nakazuje drugo tradicijo na globlji zgodovinski ravni. Razlike med oglejskim, salzburškim in rimskim obredom, kot so razvidne iz priloge, so vse le v različni razporeditvi spevov, ki so bili najbrž prav vsi splošno poznani. Razlogi za to, da so imeli posamezni spevi v različnih izročilih različna liturgična mesta, so najverjetneje le zgodovinski, in ne vsebinski: v posameznih okoljih so se v stoletjih razvile specifične prakse. V tem smislu so prikazane razlike zgolj formalne narave in bi jim bilo težko najti teološke utemeljitve. Ne glede na to je mogoče reči, da je bilo za oglejski obred npr. značilno, da je imel v tretji adventni nedelji invitatorij Surgite vigilemus, ki ga na tem mestu ni ne v salzburškem ne v rimskem obredu (možno pa je, da je kje drugje).

Preglednica 2: Primerjava ohranjenega dela sanktorala Ljubljanskega antifonala

\begin{tabular}{|c|c|c|c|}
\hline Praznik & BA & $\mathbf{S}$ & $\mathbf{R}$ \\
\hline Barbarae & $*$ & drugi oficij & - \\
\hline Nicolai & $*$ & druga razporeditev & skupni oficij \\
\hline Fabiani et Sebastiani & $*$ & $*$ & skupni oficij \\
\hline Agathae & $*$ & $*$ & druga razpor. \\
\hline Cathedrae Petri & $*$ & druga razporeditev & druga razpor. \\
\hline Matthiae & $*$ & $?$ & $*$ \\
\hline Thomae Ap. & - & - & - \\
\hline Thomae de Aquino & $*$ & $?$ & - \\
\hline Perpetuae et Felicitatis & $*$ & $?$ & $*$ \\
\hline Sanctorum XL martyrum & $*$ & $?$ & $*$ \\
\hline Gregorii & $*$ & $*$ & skupni oficij \\
\hline Hellari et Tatiani & $*$ & - & - \\
\hline In Annuntiatione & $*$ & $*$ & druga razpor. \\
\hline Chrystophori & $*$ & - & - \\
\hline In Dedicatione Michaelis & $*$ & $*$ & druga razpor. \\
\hline Omnium Sanctorum & $*$ & druga razporeditev & drugi oficij? \\
\hline
\end{tabular}

Pomenljive so razlike v sanktoralu (gl. preglednico 2) ${ }^{19}$ Kot v temporalu se tudi v sanktoralu ljubljanski rokopis popolnoma ujema z oglejskim obredom, ki ima vsa svetniška imena ljubljanskega rokopisa, iste oficije in isti razpored spevov v njih; bolj se oddaljuje od salzburškega obreda, še zlasti pa je različen od rimskega. Drugače kot v temporalu

V nekaterih primerih so spevi v kakem obredu le malenkostno premaknjeni; kljub temu so ti primeri razumljeni kot negativni (označeni z -). Psalmi, verzeti in kratki responzoriji, ki se na mestih, kjer so se dejansko peli, niso zmeraj označevali, so izpuščeni iz primerjave.

${ }^{19}$ Preglednica 2 je smiselni povzetek primerjav v prilogi. Pri zgolj rubrično navedenih svetniških imenih se primerjava omejuje na obstoj oz. neobstoj njihovega praznika (kar je naznačeno z desno poravnavo). Primerjave sanktoralnega dela so v prilogi izpeljane enako kot primerjave temporalnega dela; če praznika dani primerjalni vir nima, je z znakom - to označeno že v vrstici z naslovom praznika; črka C v naslovni vrstici pa pomeni, da je za praznik predpisan ustrezni skupni oficij. 
so razlike v sanktoralni plasti posameznih obredij vsebinske, saj je obstoj ali neobstoj določenega svetniškega kulta pomenil tudi obstoj ali neobstoj določenih teoloških vsebin. ${ }^{20}$

Pri obravnavi sanktorala ljubljanskega antifonala velja posebej izpostaviti, da vsebuje iztržek verzificiranega oficija za god oglejskih mučencev Helarja in Tacijana. ${ }^{21}$ Helar je bil po starem oglejskem izročilu oglejski škof s konca 3. stol. ali celo naslednik prvega oglejskega škofa Mohorja (Hermagorja), kar bi pomenilo, da je živel ok. dve stoletji poprej; Tacijan je bil njegov učenec. V oglejskem okolju je kult Helarja in Tacijana obstajal že v antiki in zgodnjem srednjem veku. ${ }^{22}$ Najstarejši rokopisi z njuno liturgijo so iz 12. stol., medtem ko je omenjeni verzificirani po današnjem vedenju nastal v začetku 14. stol. Kolikor je znano, obstoji le v oglejskih rokopisih: onih iz Ogleja, Čedada, Rožaca (Rosazzo), najdemo ga pa tudi v Antifonalu iz Kranja. ${ }^{23} \mathrm{Z}$ ozirom na to si je težko misliti, da bi neki novi rokopis vseboval verzificirani oficij za imenovani god, ne da bi bil namenjen cerkvi z oglejskim obredom.

Nepojasnjen ostaja domnevni skupni oficij za svetniške praznike v velikonočnem času. Kot je bilo prikazano, sta bila folija 31 in 32 skoraj gotovo sosednja (ali pa sta celo izrezka iz istega folija), na fol. 33 pa je nadaljevanje vsebine fol. 32. Na osnovi tega smemo domnevati, da pripada vsebina fol. 31-33 istemu oficiju. Nekateri ohranjeni spevi teh treh folijev imajo izrazito sanktoralno vsebino, besedila drugih so iz Janezovega Razodetja. Vsi posamični spevi fol. 31-33 se v različnih liturgičnih izročilih in rokopisih pojavljajo v omenjenem oficiju (kot tudi v nekaterih drugih oficijih); vendar pa ni bilo mogoče najti nobenega vira, v katerem bi bili kot del skupnega svetniškega oficija v velikonočnem času prav vsi. ${ }^{24}$ Kateremu oficiju pripada vsebina fol. $31-33$ in ali so bili v antifonalu I res sosednji, tako ni mogoče do konca dognati.

Podoben, čeprav nekoliko dvoumen izid da tudi primerjava ohranjenega dela psalterja. Glede razporeda psalmov se ljubljanski rokopis ujema s salzburškim obredom, ki ima na nekaterih mestih - tako npr. v sredinih jutranjicah, med antifonami po več kot le dva psalma. Očitno je bila v salzburškem obredu tedenska porazdelitev psalmov nekoliko drugačna kot v rimskem in oglejskem. Vse v ljubljanskem rokopisu ohranjene himnuse najdemo tudi v oglejskem tiskanem brevirju. ${ }^{25}$

${ }^{20}$ Nenavadna je v ljubljanskem rokopisu navedba godu apostola Tomaža po apostolu Matiji (ki je v rokopisu napačno zapisan kot Matej, »Matheus«), saj je praznik apostola Tomaža v vseh treh obredih meseca decembra. Zdi se, da je rubrika, v kateri je omenjen, jezikovno neskrbna; praznik apostola Tomaža nastopa $\mathrm{v}$ njej najverjetneje le v smislu sklica, se pravi, naj bo obredje praznika apostola Matije enako prazniku apostola Tomaža. Morda bi bilo rubriko treba urediti takole: »In vigilia beati Matthiae apostoli ut de communi apostolorum nisi venerit in dominica, ut supra in vigilia beati Thome apostoli; omnia per totum ut de communi apostolorum ...« To bi pomenilo, naj se za oba imenovana praznika vzame skupni oficij apostolov.

${ }^{21}$ Objava besedila: Analecta hymnica, 45a:109-112 (št. 43); objava monastične verzije: Baroffio, Kim, Historiae Sanctorum, 69-83; objava sekularne verzije: Snoj, Two Aquileian Poetic Offices.

22 Bratož, Krščanstvo v Ogleju, 152-155.

${ }^{23}$ Snoj, Two Aquileian Poetic Offices, ix-xi.

${ }^{24} \mathrm{Na}$ osnovi indeksov v podatkovni bazi Cantus.

${ }^{25}$ Primerjava himnarija se omejuje zgolj na prisotnost ali odsotnost himnusov v danem primerjalnem viru (in zanemarja njihove funkcije). Ker je v Ljubljani le letni del salzburškega brevirja, primerjave s salzburškim obredom ni bilo mogoče izpeljati do konca. 
Govoreč o liturgičnih značilnostih rekonstruiranega antifonala lahko omenimo še nekaj. Ko se v ustanovni listini cesarja Friderika III. navajajo teološki razlogi za ustanovitev nove škofije, je določeno tudi tole:

Hinc est quod ad laudem superbenedictae trinitatis, et in honorem dictae gloriosae Virginis Mariae, beatorumque Petri et Pauli apostolorum, Christophori, Hermachori, et Fortunati martyrum, Martini et Nicolai pontificum, sanctorumque omnium, pro divini cultus augmento ... cathedram episcopalem ... erigere et fundare decrevimus ...

Vsled tega smo se za povečanje božjega čaščenja in v čast imenovane slavne Device Marije, svetih apostolov Petra in Pavla, mučencev Krištofa, Mohorja in Fortunata, škofov Martina in Nikolaja kot tudi vseh svetnikov odločili postaviti in osnovati škofijski sedež ... ${ }^{26}$

V listini navedena imena niso poljubna. Mohor, prvi oglejski škof, in njegov učenec Fortunat sta bila nedvomno izbrana kot zavetnika oglejskega patriarhata, na ozemlju katerega je nastala nova škofija, Nikolaj kot patron nove stolnice; morda bi bilo mogoče najti utemeljitev tudi za navedbo škofa Martina in mučenca Krištofa. S temi imeni se da povezati vsebina ohranjenih fragmentov. Obstoj oficija sv. Nikolaja v antifonalu I sicer ni dokaz, da je bil rokopis izdelan prav za ljubljansko stolnico, vsekakor pa bi bilo nenavadno, če antifonal ljubljanske stolnice ne bi vseboval oficija njenega patrona. Morda je zgolj naključje, da najdemo v antifonalu II iztržek iz Krištofovega oficija, morda pa so k temu navedli kaki drugi, z listinsko navedbo svetnika povezani razlogi.

Čeprav ni mogoče razložiti prav vsakega detajla, lahko na osnovi prikazanih primerjav zaključimo, da pripadajo ohranjeni fragmenti rokopisom z oglejskim obredom.

\section{IV}

Kot je bilo omenjeno, so se obravnavani fragmenti ohranili v vezavah raznih ljubljanskih arhivalij. Oglejmo si natančneje, katere so te arhivalije in iz katerega časa izhajajo, saj si je po tej poti možno ustvariti predstavo o času in kraju uničenja rokopisov, ki so jim v njihovih vezavah ohranjeni fragmenti nekdaj pripadali.

Preglednica 3 je vsekakor zanimiva, saj je iz nje mogoče razbrati skorajda kronologijo uničenja obravnavanih treh kodeksov. Foliji Psalterja so se vsi ohranili v vezavah ljubljanskih mestnih knjig iz let 1653 in 1654. To pomeni, da je zapadel uničenju najkasneje v petdesetih letih 17. stol. Večina folijev prvega dela antifonala I je prav tako preživela v vezavah ljubljanskih mestnih knjig, poleg tega pa še v vezavah arhivalij ljubljanske škofije, župnije Komenda, graščine Zalog, ceha ljubljanskih jermenarjev in v vezavi dveh zvezkov raznih drobnih tiskov, ki jih je zbral in verjetno tudi dal vezati Frančišek Jožef Thallmainer (1698-1768). Kot je znano, je bil Thallmainer od leta 1702 pa vse do smrti knjižničar Javne škofijske knjižnice v Ljubljani (predhodnice zdajšnje Semeniške knjižnice). ${ }^{27} \mathrm{Z}$ ozirom na čas izdaje najmlajših tiskov obeh Thallmainerjevih zvezkov,

\footnotetext{
${ }^{26}$ Prevod J. Snoj.

${ }^{27}$ Smolik, »Franciscus Josephus Thallmainer«, 48.
} 
le-ta nista mogla biti vezana pred letom 1708. Nobena od arhivalij z listi iz antifonala I ni starejša od leta 1683, najmlajše pa so z začetka 18. stol. Zanimivo je, da so knjige s foliji iz njegovega adventno-božičnega dela $v$ vezavah s konca devetdesetih let, oni iz njegovega velikonočnega in sanktoralnega pa v vezavah iz osemdesetih let 17. stol.; to daje vtis, kot da bi bil antifonal I razrezan na dve polovici in bi se posamezni foliji trgali najprej iz druge, kasneje pa iz prve polovice. V nekaj primerih je celo tako, da sta se po dva in dva sosednja folija ohranila na dveh arhivalijah iz sosednjih let, kar daje vtis zaporednega postopnega izrezovanja iz fasciklov, ki jih je imel knjigovezec pri roki. Antifonal I, prav tako pa tudi antifonal II sta bila zelo verjetno uničena v začetku osemdesetih let. Vse navedene arhivalije so ali iz Ljubljane ali iz njene bližnje okolice. To pomeni, da so bili trije rokopisi v času svojega uničenja tu, v Ljubljani.

Preglednica 3: Način ohranitve obravnavanih fragmentov

\begin{tabular}{|c|c|c|}
\hline Fol. & Mesto ohranitve & Sign. ohranjenih folijev \\
\hline \multicolumn{3}{|c|}{ Antifonal I } \\
\hline 1 & Knjiga izdatkov za leto 1698 (II) & \multirow{9}{*}{$\begin{array}{l}\text { ZAL, Makulature II (3), } \\
\text { mapa } 22\end{array}$} \\
\hline 2 & Knjiga prejemkov za leto 1698 (II) & \\
\hline 3 & Knjiga izdatkov za leto 1698 (I) & \\
\hline 4 & Računi mesta Lj. - Špitala za leta 1698-1701 & \\
\hline 5 & $?$ & \\
\hline 6 & Knjiga izdatkov za leto 1701 & \\
\hline 7 & Knjiga prejemkov za leto 1698 (I) & \\
\hline 8 & Davčna knjiga mesta Ljubljane 1696 & \\
\hline 9 & Urbar mestnega računovodstva za leto 1697 & \\
\hline 10 & Cehovska knjiga jermenarjev 1700-1860 & ZAL, Cod. XX/52 \\
\hline 11 & Knjiga prejemkov za leto 1699 & \multirow{2}{*}{$\begin{array}{l}\text { ZAL, Makulature II (3), } \\
\text { mapa } 22\end{array}$} \\
\hline 12 & Urbar mestnega računovodstva za leto 1698 & \\
\hline 13 & Komenda, P 1717-1750 & NŠAL, ŽA, Matice \\
\hline 14 & Zalog, Urbar 1695-1699 & ARS, Urbarji, I/55u \\
\hline 15 & Škofijski protokoli $1684-1685$ & $\begin{array}{l}\text { NŠAL, Škofijski protokoli, } \\
\text { fasc. } 8, \text { št. } 13\end{array}$ \\
\hline 16 & Vizitacije 1684 & $\begin{array}{l}\text { NŠAL, Vizitacije - protokoli, } \\
\text { fasc. 2, št. } 5\end{array}$ \\
\hline 17 & Knjiga izdatkov za leto 1684 & \multirow{8}{*}{$\begin{array}{l}\text { ZAL, Makulature II (3), } \\
\text { mapa } 22\end{array}$} \\
\hline 18 & Davčna knjiga mesta Ljubljane 1683 & \\
\hline 19 & Knjiga prejemkov za leto 1684 & \\
\hline 20 & Davčna knjiga mesta Ljubljane 1684 & \\
\hline 21 & Davčna knjiga mesta Ljubljane 1685 & \\
\hline 22 & Urbar mestnega računovodstva za leta $1688-1690$ & \\
\hline 23 & Davčna knjiga mesta Ljubljane1687 & \\
\hline 24 & Knjiga prejemkov za leto 1689 & \\
\hline 25 & $?$ & NŠAL, Pergamentni ovitki \\
\hline
\end{tabular}




\begin{tabular}{|c|c|c|}
\hline Fol. & Mesto ohranitve & Sign. ohranjenih folijev \\
\hline 26 & Knjiga prejemkov za leto 1688 & \multirow{6}{*}{$\begin{array}{l}\text { ZAL, Makulature II (3), } \\
\text { mapa } 22\end{array}$} \\
\hline 27 & Knjiga prejemkov za leto 1687 & \\
\hline 28 & Knjiga izdatkov za leto 1685 & \\
\hline 29 & Knjiga izdatkov za leto 1686 & \\
\hline 30 & Priloge 1686 & \\
\hline 31 & Knjiga prejemkov za leto 1685 & \\
\hline 32 & Thallmainerjeva zbirka libretov (1655-1708) & SK, Z III 3 \\
\hline 33 & Thallmainerjeva zbirka libretov (1672-1690) & SK, Z III 4 \\
\hline 34 & Urbar mestnega računovodstva za leto 1684 & $\begin{array}{l}\text { ZAL, Makulature II (3), } \\
\text { mapa } 22\end{array}$ \\
\hline 35 & ŠAL/KAL, Urbar 1684-1685 & NŠAL/KAL, Urbar 9 \\
\hline \multicolumn{3}{|c|}{ Antifonal II } \\
\hline 1 & $?$ & \multirow{2}{*}{ SK, brez sign. } \\
\hline 2 & $?$ & \\
\hline 3 & Davčna knjiga mesta Ljubljane 1695 & \multirow{2}{*}{$\begin{array}{l}\text { ZAL, Makulature II (2), mapa } \\
14\end{array}$} \\
\hline 4 & Davčna knjiga mesta Ljubljane 1695 & \\
\hline 5 & Dol pri Ljubljani, R 1688-1730 & NŠAL, ŽA, Matice \\
\hline 6 & Vače, Urbar 1648 & $\begin{array}{l}\text { NŠAL/ŽA, Razne knjige, Vače, } \\
\text { fasc. } 3\end{array}$ \\
\hline \multicolumn{3}{|c|}{ Psalter } \\
\hline 1,3 & Knjiga izdatkov 1654 & \multirow{5}{*}{$\begin{array}{l}\text { ZAL, Makulature II (2), } \\
\text { mapa } 13\end{array}$} \\
\hline 2,6 & $\begin{array}{l}\text { Davčna knjiga za Stari trg } 1653 \\
\text { Davčna knjiga za Novi trg } 1653\end{array}$ & \\
\hline 4 & Knjiga prejemkov 1654 & \\
\hline 5 & $?$ & \\
\hline 7,8 & Davčna knjiga za Mestni trg 1653 & \\
\hline
\end{tabular}

Da bi bilo uničenje obravnavanih treh rokopisov možno videti v pravi luči, ga je treba interpretirati na ozadju liturgične zgodovine časa. Kot je dobro znano, je skušal tridentinski koncil v drugi pol. 16. stol. poenotiti liturgijo. Lastne liturgične rede je dovolil le tistim cerkvam, ki so jih imele že več kot dve stoletji. Med temi je bil nedvomno tudi oglejski patriarhat. Vendar pa je bil v oglejskem patriarhatu stari liturgični red že konec 16. stol. zamenjan z novim, potridentinskim, ki je bil v bistvu rimski (v zgoraj omenjenem smislu). V ljubljanski škofiji je bilo drugače. Ker je bila z bulo Romanus Pontifex izvzeta iz oglejskega patriarhata, bi bilo pričakovati, da bo že konec 16. stol. menjala oglejski obred za rimski, vendar se to ni zgodilo. Škof Hren (1598-1630) je bil očitno zagovornik oglejskega obreda, saj sledi njegov slovenski lekcionar iz leta 1612 ali 1613 oglejskemu liturgičnemu redu (Evangelia inu lystuvi). Rimski obred se je v ljubljanski škofiji začel uvajati šele za časa njegovega naslednika Rinalda Scarlichija (1630-1640); v vizitacijskih zapisnikih tega škofa se pogosto bere, naj se stare oglejske knjige zamenjajo z novimi. A zdi se, da njegova prizadevanja niso bila uspešna; iz zapisnikov sinode, ki jo je leta 1666 
sklical škof Rabatta, je razvidno, da je bil v škofiji še vedno razširjen stari obred. Do njegove dokončne odprave, čeprav ne povsem korenite, je prišlo tako šele po tej sinodi. ${ }^{28}$ S tem smo se močno približali času, iz katerega izhajajo arhivalije, na katerih so se ohranili posamezni listi obravnavanih treh rokopisov. Zelo verjetno so bili uničeni kot nosilci stare in neveljavne oglejske liturgije, in sicer prav v času, ko je bila le-ta v ljubljanski škofiji dokončno zamenjana $\mathrm{z}$ rimsko.

Strnimo v doslejšnji razpravi ugotovljena dejstva: 1. Rokopisi, ki so jim obravnavani fragmenti pripadali, so nastali bodisi v poznem 15. ali zgodnjem 16. stol., se pravi v času, ko se je v ljubljanski stolnici začelo opravljati redno koralno bogoslužje. 2. Nedvomno so pripadali oglejskemu obredu, ki je bil z ustanovno listino predpisan za bogoslužje novoustanovljenega kapitlja. 3. Uničeni so bili v Ljubljani v drugi pol. 17. stol., v času, ko se je v ljubljanski škofiji uvajal novi rimski obred, kar je vodilo k uničevanju starih oglejskih liturgičnih rokopisov. Na osnovi teh dejstev je mogoče utemeljeno postaviti hipotezo, da so ohranjeni fragmenti ostanki dvodelnega antifonala in psalterja ljubljanskega kapitlja.

\section{Priloga}

Rekonstrukcija antifonala in psalterja ljubljanske škofije

Antifonal I

\begin{tabular}{|c|c|c|c|c|}
\hline & Ljubljana & $\mathbf{A}$ & $\mathbf{S}$ & $\mathbf{R}$ \\
\hline & 1 & & & \\
\hline & [Fer. VI. post Dom. II. Adventus] & & & \\
\hline \multirow[t]{2}{*}{ An.M } & Erumpant montes jucunditatem & $*$ & $*$ & - \\
\hline & Sabbato Invitatorium & & & \\
\hline Inv. & Regem venturum* & $?$ & $?$ & $?$ \\
\hline Re. & Jerusalem plange* & $?$ & $?$ & $?$ \\
\hline Re. & Egredietur* & $?$ & $?$ & $?$ \\
\hline \multirow[t]{2}{*}{ Re. } & Rex noster* & $?$ & $?$ & $?$ \\
\hline & Ad benedictus antiphona & & & \\
\hline \multirow[t]{2}{*}{ An.B } & Dicite pusillanimes* & $*$ & $*$ & - \\
\hline & $\begin{array}{l}\text { Require ut supra in vesperis. Ad vesperas super } \\
\text { psalmos }\end{array}$ & & & \\
\hline An. & Levabit dominus signum & $*$ & - & - \\
\hline Ps. & $\begin{array}{l}\text { Benedictus dominus Deus meus ad proelium* cum } \\
\text { reliquis }\end{array}$ & & & \\
\hline Re. & Qui venturus est veniet & $*$ & - & - \\
\hline
\end{tabular}

${ }^{28}$ Ušeničnik, »Oglejski obred«, 119-121, 123-126. - Od druge pol. 17. stol. dalje se je oficijsko bogoslužje v ljubljanski stolnici izvajalo po tiskanih knjigah z rimskim obredom. Kokole, »Cerkvena glasba v ljubljanski škofiji«, 554 (faksimila na 555). 


\begin{tabular}{|c|c|c|c|c|}
\hline & Ljubljana & $\mathbf{A}$ & $\mathbf{S}$ & $\mathbf{R}$ \\
\hline \multirow[t]{2}{*}{ V. } & Ex Sion species & $*$ & & \\
\hline & Hymnus et versiculus ut supra. Super Magnificat & & & \\
\hline An.M & Ante me non est formatus & $*$ & $*$ & $*$ \\
\hline \multirow[t]{2}{*}{ Нy. } & Verbum supernum* [intra rubricam illegibilem] & $*$ & $?$ & $?$ \\
\hline & Dominica tercia & & & \\
\hline \multirow[t]{2}{*}{ Inv. } & Surgite vigilemus & $*$ & - & - \\
\hline & 2 & & & \\
\hline \multirow[t]{2}{*}{ Ps. } & Venite* & & & \\
\hline & $\begin{array}{l}\text { [Ad Matutinum } \\
\text { In I. Nocturno] } \\
\text { Antiphone et psalmi ut supra }\end{array}$ & & & \\
\hline Re.1 & Ecce apparebit dominus & $*$ & $*$ & $*$ \\
\hline V. & Ecce dominator dominus & $*$ & $*$ & - \\
\hline \multirow[t]{4}{*}{ Re.1 } & Bethlehem civitas Dei & $*$ & $*$ & $*$ \\
\hline & lacuna & & & \\
\hline & 3 & & & \\
\hline & [In II. Nocturno] & & & \\
\hline Re. 2 & Aegypte noli flere & $*$ & $*$ & - \\
\hline V. & Ecce dominator dominus & $*$ & $*$ & \\
\hline Re.3 & Prope est ut veniat tempus & $*$ & $*$ & - \\
\hline \multirow[t]{2}{*}{$\mathrm{V}$. } & Qui venturus est & $*$ & $*$ & \\
\hline & [In III. Nocturno] & & & \\
\hline \multirow[t]{4}{*}{ Re.1 } & Descendet dominus sicut pluvia & $*$ & $*$ & - \\
\hline & lacuna & & & \\
\hline & 4 & & & \\
\hline & [Feria III. post Dom. III. Adventus] & & & \\
\hline \multirow[t]{2}{*}{ An.M } & Elevare elevare consurge & $*$ & $*$ & $*$ \\
\hline & Feria quarta. Invitatorium ut supra & & & \\
\hline Re.1 & Descendit* & $?$ & $?$ & $?$ \\
\hline Re. 2 & Veni domine* & $?$ & $?$ & $?$ \\
\hline \multirow[t]{2}{*}{ Re.3 } & Docebit nos* & $?$ & $?$ & $?$ \\
\hline & Ad benedictus & & & \\
\hline \multirow[t]{2}{*}{ An.B } & Ponam in Sion & $*$ & $*$ & $*$ \\
\hline & Ad vesperas ut supra ad Magnificat & & & \\
\hline \multirow[t]{2}{*}{ An.M } & Ponent domino gloriam & $*$ & $*$ & $*$ \\
\hline & Feria quinta. Invitatorium ut supra & & & \\
\hline Re.1 & Ecce apparebit* & $?$ & $?$ & $?$ \\
\hline Re. 2 & Bethlehem civitas* & $?$ & $?$ & $?$ \\
\hline \multirow[t]{2}{*}{ Re.3 } & Qui venturus* & $?$ & $?$ & $?$ \\
\hline & Ad benedictus & & & \\
\hline \multirow[t]{2}{*}{ An.B } & Consolamini consolamini & $*$ & $*$ & $*$ \\
\hline & Ad suffragia ut supra. Ad primam. & & & \\
\hline An. & Ponam domine* ut supra. Ad magnificat & $?$ & $?$ & $?$ \\
\hline An.M & Laetamini cum Jerusalem & $*$ & $*$ & $*$ \\
\hline
\end{tabular}




\begin{tabular}{|c|c|c|c|c|}
\hline & Ljubljana & $\mathbf{A}$ & $\mathbf{S}$ & $\mathbf{R}$ \\
\hline \multirow[t]{4}{*}{ An.M } & Omnis vallis [alia] & $*$ & - & - \\
\hline & lacuna & & & \\
\hline & 5 & & & \\
\hline & $\begin{array}{l}\text { [Dominica IV. Adventus } \\
\text { In II. Nocturno] }\end{array}$ & & & \\
\hline Re.3 & Virgo Israel revertere & $*$ & $*$ & $*$ \\
\hline \multirow[t]{2}{*}{ V. } & A solis ortu et usque ad occasum & $*$ & $*$ & - \\
\hline & [In III. Nocturno] & & & \\
\hline Re.1 & Juravi dicit dominus & $*$ & $*$ & $*$ \\
\hline V. & A solis ortu et occasu & $*$ & * & - \\
\hline Re. 2 & Non discedimus & $*$ & $*$ & $*$ \\
\hline \multirow[t]{4}{*}{$\mathrm{V}}$. & Domine Deus & $*$ & $*$ & - \\
\hline & lacuna & & & \\
\hline & 6 & & & \\
\hline & $\begin{array}{l}\text { [Feria II. ante Nativitatem Domini } \\
\text { Ad Laudes] }\end{array}$ & & & \\
\hline An.2 & Cum venerit filius hominis & $*$ & $*$ & $*$ \\
\hline An.3 & Ecce jam venit plenitudo & $*$ & $*$ & $*$ \\
\hline \multirow[t]{2}{*}{ An. 4} & Haurietis aquas & $*$ & $*$ & $*$ \\
\hline & Super benedictus & & & \\
\hline \multirow[t]{2}{*}{ An.B } & Egredietur virga de radice & $*$ & $*$ & $*$ \\
\hline & ultima aniphona in laudibus ut supra & & & \\
\hline \multirow[t]{2}{*}{ An.5 } & Egredietur dominus & $*$ & $*$ & $*$ \\
\hline & $\begin{array}{l}\text { Ad horas ut supra. Ad magnificat antiphona } \text { O. que } \\
\text { contingit. tunc suffragia non dicantur. ad completorium } \\
\text { de dominica preterita nisi alia assignentur. Feria III. } \\
\text { Invitatorium antiphone et psalmi feriales ut supra }\end{array}$ & & & \\
\hline \multirow[t]{4}{*}{ Re.1 } & Egredietur dominus & $?$ & $?$ & $?$ \\
\hline & lacuna & & & \\
\hline & 7 & & & \\
\hline & $\begin{array}{l}\text { [Sabbato ante Nativitatem } \\
\text { Ad Laudes] }\end{array}$ & & & \\
\hline An. 4 & Exspectetur sicut pluvia & $*$ & $*$ & $*$ \\
\hline \multirow[t]{2}{*}{ An.5 } & Exspectabo dominum salvatorem & $*$ & - & $?$ \\
\hline & ymnus et versiculus ut supra. Ad benedictus & & & \\
\hline \multirow[t]{2}{*}{ An.B } & Omnis vallis implebitur & $*$ & $*$ & - \\
\hline & $\begin{array}{l}\text { Suffragia ut supra. Ad primam ut supra per totum. Ad } \\
\text { vesperas antiphone et psalmi feriales. versiculus ut } \\
\text { supra. Super magnificat Antiphona } \text { O. que contingit. } \\
\text { Ad completorium ut supra. Antiphonae maiores que } \\
\text { dicuntur super magnificat incipiendo. In secundis } \\
\text { vesperis beate virginis lucie singulo die. usque ad } \\
\text { Vigiliam nativitatis domini. antiphone. Et prima }\end{array}$ & & & \\
\hline An. & O sapientia & $*$ & $*$ & * \\
\hline An. & $\mathrm{O} \ldots$ & & & \\
\hline
\end{tabular}




\begin{tabular}{|c|c|c|c|c|}
\hline & Ljubljana & $\mathbf{A}$ & $\mathbf{S}$ & $\mathbf{R}$ \\
\hline \multicolumn{5}{|c|}{ lacuna } \\
\hline & 8 & & & \\
\hline & [In Vigilia Nativitatis] & & & \\
\hline Re.3 & Sanctificamini filii & $*$ & $*$ & $*$ \\
\hline \multirow[t]{2}{*}{ V. } & Ecce dominus veniet & $*$ & $*$ & - \\
\hline & Ad laudes & & & \\
\hline An.1 & Scitote quia prope est & $*$ & - & - \\
\hline An. 2 & Hodie scietis quia & $*$ & $*$ & $*$ \\
\hline An. 3 & Crastina die delebitur & $*$ & $*$ & $*$ \\
\hline \multirow[t]{4}{*}{ An. 4} & Exspectetur sicut pluvia & $*$ & $?$ & - \\
\hline & lacuna & & & \\
\hline & 9 & & & \\
\hline & $\begin{array}{l}\text { [In Nativitate Domini } \\
\text { In I. Nocturno] }\end{array}$ & & & \\
\hline Re.3 & Descendit de coelis & $*$ & $*$ & - \\
\hline $\mathrm{V}$. & Gloria patri & $?$ & $?$ & \\
\hline \multirow[t]{2}{*}{ Pr. } & Facturae plasmator & $?$ & $?$ & \\
\hline & In II. nocturno & & & \\
\hline An.1 & Suscepimus Deus misericordiam & $*$ & $*$ & $*$ \\
\hline Ps. & Magnus dominus* & & & \\
\hline \multirow[t]{4}{*}{ An.2 } & Orietur in diebus domini & * & $*$ & $*$ \\
\hline & lacuna & & & \\
\hline & 10 & & & \\
\hline & $\begin{array}{l}\text { [Ioannis Apostoli et Evangelistae } \\
\text { In I. Nocturno] }\end{array}$ & & & \\
\hline Re. 2 & In illo die suscipiam te servum & $*$ & $*$ & - \\
\hline $\mathrm{V}$. & In tribulatione invocasti me & $*$ & $*$ & \\
\hline \multirow[t]{4}{*}{ Re. 3} & Qui vicerit faciam illum & $*$ & $*$ & - \\
\hline & lacuna & & & \\
\hline & 11 & & & \\
\hline & [In III. Nocturno] & & & \\
\hline An.2 & Expandens manus suas & $*$ & - & - \\
\hline An. 3 & Domine suscipe me & $*$ & - & - \\
\hline Ve. & Nimis honorati sunt amici tui Deus* & & & \\
\hline \multirow[t]{2}{*}{ Re.1 } & Iste est Iohannes & $*$ & - & - \\
\hline & 12 & & & \\
\hline V. & Valde honorandus est & $*$ & & \\
\hline Re.2 & Diligebat autem eum Jesus & * & - & - \\
\hline \multirow[t]{4}{*}{ V. } & In cruce denique & * & & \\
\hline & lacuna & & & \\
\hline & 13 & & & \\
\hline & $\begin{array}{l}\text { [Innocentum Martyrum } \\
\text { In I. Nocturno] }\end{array}$ & & & \\
\hline Re.1 & Sub altare Dei & $*$ & $*$ & - \\
\hline
\end{tabular}




\begin{tabular}{|c|c|c|c|c|}
\hline & Ljubljana & $\mathbf{A}$ & $\mathbf{S}$ & $\mathbf{R}$ \\
\hline V. & Vidi sub altare & $*$ & $*$ & \\
\hline Re.2 & Effuderunt sanguinem sanctorum & $*$ & $*$ & - \\
\hline \multirow[t]{4}{*}{$\mathrm{V}}$. & Vindica domine & $*$ & $*$ & \\
\hline & lacuna & & & \\
\hline & 14 & & & \\
\hline & $\begin{array}{l}\text { [Dominica II. post Epiphaniam } \\
\text { In II. Nocturno] }\end{array}$ & & & \\
\hline Re. 2 & Diligam te domine & $*$ & - & $*$ \\
\hline V. & Laudans invocabo dominum & $*$ & - & - \\
\hline \multirow[t]{4}{*}{ Re. 3} & Domini est terra et plenitudo & $*$ & - & $*$ \\
\hline & lacuna & & & \\
\hline & 15 & & & \\
\hline & $\begin{array}{l}\text { [Dominica Resurrectionis } \\
\text { Ad III.] }\end{array}$ & & & \\
\hline An. & Surrexit Christus et illuxit & $*$ & - & - \\
\hline Reb. & Quem quaeris mulier & & & \\
\hline V. & Viventem cum mortuis & & & \\
\hline \multirow[t]{2}{*}{ Ve. } & Tulerunt dominum meum & & & \\
\hline & [Ad VI.] & & & \\
\hline An. & Cito euntes dicite & $*$ & - & - \\
\hline \multirow[t]{4}{*}{ Reb. } & Tulerunt dominum & & & \\
\hline & lacuna & & & \\
\hline & 16 & & & \\
\hline & [Feria III. post Dominicam Resurrectionis] & & & \\
\hline \multirow[t]{2}{*}{ An.M } & Videte manus meas & $*$ & $*$ & $*$ \\
\hline & $\begin{array}{l}\text { Ad completorium ut supra. } \\
\text { Feria quarta } \\
\text { Ad matutinum }\end{array}$ & & & \\
\hline An.1 & Gavisi sunt discipuli & $*$ & $?$ & - \\
\hline Ps. & Salvum me fac* & & & \\
\hline Ps. & Usquequo domine* & & & \\
\hline Ps. & Dixit insipiens* & & & \\
\hline Ve. & Quem quaeris mulier* & & & \\
\hline \multirow[t]{2}{*}{ Re. 1} & Ecce vicit leo & $*$ & $*$ & $*$ \\
\hline & lacuna & & & \\
\hline
\end{tabular}

\begin{tabular}{|l|l|c|c|c|}
\hline & Ljubljana & BA & S & R \\
\hline & 17 & & & \\
\hline & $\begin{array}{l}\text { [Barbarae virginis et martyris } \\
\text { In III. Nocturno }]\end{array}$ & & & - \\
\hline An.2 & Perambulans vero immaculata & $*$ & - & \\
\hline An.3 & Ingressa famula Dei & $*$ & - & \\
\hline Ve. & Audi filia et vide* & & & \\
\hline Re.1 & Patrato namque tam & $*$ & - & \\
\hline V. & Ignis subito & $*$ & & \\
\hline
\end{tabular}




\begin{tabular}{|c|c|c|c|c|}
\hline & Ljubljana & BA & $\mathbf{S}$ & $\mathbf{R}$ \\
\hline \multirow[t]{2}{*}{ Re. 2} & O nimis felix et elegans & $*$ & - & \\
\hline & 18 & & & \\
\hline V. & Intercede pro tuis supplicibus & $*$ & & \\
\hline \multirow[t]{4}{*}{ Re.3 } & Regnum mundi & $*$ & - & \\
\hline & lacuna & & & \\
\hline & 19 & & & \\
\hline & [Ad Laudes] & & & \\
\hline \multirow[t]{2}{*}{ An.B } & Igitur milites circumduxerunt & $*$ & - & \\
\hline & $\begin{array}{l}\text { Ad horas diei Antiphonae laudum dicantur. } \\
\text { Responsoria et versiculi ut in communi de virginibus. } \\
\text { In secundis vesperis antiphone de laudibus. ymnus et } \\
\text { versiculus ut de virginibus. Super magnificat }\end{array}$ & & & \\
\hline \multirow[t]{2}{*}{ An.M } & O Barbara martyr & $*$ & - & \\
\hline & De sancto Nicolao. Ad vesperas super psalmos & & & $\mathrm{C}$ \\
\hline \multirow[t]{2}{*}{ An. } & Sancte Nicolae confessor & $*$ & - & \\
\hline & psalmi omnia laudate & & & \\
\hline \multirow[t]{4}{*}{ Re. } & Beatus Nicolaus iam & $*$ & $*$ & \\
\hline & lacuna & & & \\
\hline & 20 & & & \\
\hline & $\begin{array}{l}\text { [Fabiani et Sebastiani } \\
\text { In I. Nocturno] }\end{array}$ & & & $\mathrm{C}$ \\
\hline Re.3 & Erat namque in sermone & $*$ & $*$ & \\
\hline \multirow[t]{2}{*}{ V. } & In commisso & $*$ & & \\
\hline & In secundo nocturno & & & \\
\hline An.1 & Ad hoc tantum & $*$ & $*$ & \\
\hline An.2 & Clarissimis cottidie viris & $*$ & $*$ & \\
\hline An.3 & Sebastianus vir christianissimus & $*$ & $*$ & \\
\hline Ve. & Exsultent justi in conspectu* & & & \\
\hline \multirow[t]{4}{*}{ Re.1 } & Christo cottidie sedulum & $*$ & $*$ & \\
\hline & lacuna & & & \\
\hline & 21 & & & \\
\hline & $\begin{array}{l}\text { [Agathae virginis } \\
\text { In I. Nocturno] }\end{array}$ & & & \\
\hline Re. 2 & Vidisti domine et exspectasti & $*$ & $*$ & - \\
\hline V. & Propter veritatem & $*$ & $*$ & \\
\hline Re.3 & Quis es tu qui venisti & $*$ & $*$ & $*$ \\
\hline \multirow[t]{2}{*}{$\mathrm{V}$. } & Nam et ego & * & $*$ & * \\
\hline & In secundo nocturno & & & \\
\hline An.1 & Agatha sancta dixit & $*$ & $*$ & $*$ \\
\hline An.2 & Si ignem adhibeas & $*$ & $*$ & $*$ \\
\hline \multirow[t]{4}{*}{ An.3 } & $?$ & & & \\
\hline & lacuna & & & \\
\hline & 22 & & & \\
\hline & $\begin{array}{l}\text { [Cathedrae Sancti Petri } \\
\text { Ad Laudes] }\end{array}$ & & & \\
\hline
\end{tabular}




\begin{tabular}{|c|c|c|c|c|}
\hline & Ljubljana & BA & $\mathbf{S}$ & $\mathbf{R}$ \\
\hline \multirow[t]{2}{*}{ An.5 } & Tu es Petrus & * & $*$ & - \\
\hline & Super benedictus [in fine rubricae illegibilis] & & & \\
\hline \multirow[t]{2}{*}{ An.B } & Quodcumque ligaveris & $*$ & - & $*$ \\
\hline & In secundis vesperis & & & \\
\hline \multirow[t]{2}{*}{ An. } & Juravit dominus* & $*$ & $*$ & - \\
\hline & ymnus et versiculus ut supra. Super magnificat & & & \\
\hline \multirow[t]{3}{*}{ An.M } & Beatus Petrus apostolus & $*$ & - & - \\
\hline & $\begin{array}{l}\text { In vigilia beati mathei apostoli. Ut de communi } \\
\text { apostolorum nisi venerit in dominica ut supra. In vigilia } \\
\text { beati Thome apostoli. omnia per totum ut de communi } \\
\text { apostolorum. In festo thome de aquino. omnia ut de } \\
\text { uno simplici confessore. In festo perpetue et felicitatis. } \\
\text { Omnia per totum ut in communi plurimorum martirum. } \\
\text { In festo sanctorum Xl martirum. ut de pluribus } \\
\text { martiribus. }\end{array}$ & & & \\
\hline & De sancto gregorio papa. Ad vesperas & & & $\mathrm{C}$ \\
\hline An.1 & Similabo eum* & $*$ & - & \\
\hline \multirow[t]{2}{*}{ Ps. } & Laudate pueri* & & & \\
\hline & $\begin{array}{l}\text { cum reliquis. ymnus et versiculus de uno confessore et } \\
\text { pontifice }\end{array}$ & & & \\
\hline \multirow[t]{2}{*}{ Re. } & O pastor apostolice & $*$ & $*$ & \\
\hline & 23 & & & \\
\hline $\mathrm{V}$. & Memor esto & $*$ & $*$ & \\
\hline \multirow[t]{2}{*}{ V. } & Gloria patri & $?$ & $?$ & \\
\hline & Super magnificat & & & \\
\hline An.M & Gloriosa sanctissimi & $*$ & $*$ & \\
\hline \multirow[t]{4}{*}{ Ps. } & $?$ & & & \\
\hline & lacuna & & & \\
\hline & 24 & & & \\
\hline & [In I. Nocturno] & & & \\
\hline Re. 2 & Videns ergo vir beatus & $*$ & $*$ & \\
\hline $\mathrm{V}$. & Quoniam domini est regnum & $*$ & $*$ & \\
\hline Re.3 & Dum oraret in obscuro & $*$ & $*$ & \\
\hline $\mathrm{V}$. & Quia misericordiam & $*$ & $*$ & \\
\hline \multirow[t]{2}{*}{$\mathrm{V}$. } & Gloria patri & $*$ & $?$ & \\
\hline & In II. nocturno & & & \\
\hline \multirow[t]{2}{*}{ An.1 } & Gregorius ut creditur & $*$ & $*$ & \\
\hline & 25 & & & \\
\hline An.2 & Studiis liberalibus & $*$ & $*$ & \\
\hline An.3 & Hic ab adolescentia & $*$ & $*$ & \\
\hline Ve. & Posuisti domine super* & & & \\
\hline \multirow[t]{3}{*}{ Re.1 } & Propter intolerabiles & $*$ & $*$ & \\
\hline & lacuna & & & \\
\hline & 26 & & & \\
\hline
\end{tabular}




\begin{tabular}{|c|c|c|c|c|}
\hline & Ljubljana & BA & $\mathbf{S}$ & $\mathbf{R}$ \\
\hline & $\begin{array}{l}\text { [Hellari et Tatiani } \\
\text { In I. Nocturno] }\end{array}$ & & - & - \\
\hline Re.3 & Plagis scorpionibus & $*$ & & \\
\hline $\mathrm{V}$. & Tanti fac itineris & $*$ & & \\
\hline \multirow[t]{2}{*}{$\mathrm{V}$. } & Doxa patri & $*$ & & \\
\hline & In II. nocturno & & & \\
\hline An.1 & Orat praesul cum timore & $*$ & & \\
\hline An.2 & Hellarus dum Christum orat & $*$ & & \\
\hline Ps. & Domine dominus noster* & & & \\
\hline \multirow[t]{2}{*}{ An. 3} & In aetate juvenili & $*$ & & \\
\hline & 27 & & & \\
\hline Ps. & Domine quis habitabit* & & & \\
\hline Ve. & Exsultent justi in conspectu Dei* & & & \\
\hline Re.1 & Tantoque beato & $*$ & & \\
\hline V. & Tremit tota civitas & $*$ & & \\
\hline Re. 2 & Flantis terra claruit & $*$ & & \\
\hline \multirow[t]{4}{*}{$\mathrm{V}$. } & Sunt haec plante & $*$ & & \\
\hline & lacuna & & & \\
\hline & 28 & & & \\
\hline & [Ad Laudes] & & & \\
\hline An.1 & Pastor Aquilegiae & $*$ & & \\
\hline An.2 & Defleat gentilitas & $*$ & & \\
\hline An. 3 & Deo cum laeticia & $*$ & & \\
\hline An. 4 & Largus sive largius & $*$ & & \\
\hline An.5 & Recolentes proelia tua & $*$ & & \\
\hline \multirow[t]{4}{*}{ Ps. } & $?$ & & & \\
\hline & lacuna & & & \\
\hline & 29 & & & \\
\hline & $\begin{array}{l}\text { [In Annuntiatione } \\
\text { In III. Nocturno] }\end{array}$ & & & \\
\hline Re.3 & Quomodo fiet istud & $*$ & $*$ & - \\
\hline \multirow[t]{2}{*}{$\mathrm{V}$. } & Ideoque et quod & $*$ & $*$ & \\
\hline & Ad laudes & & & \\
\hline An.1 & Quando venit ergo & $*$ & $*$ & - \\
\hline \multirow[t]{3}{*}{ An. 2} & Verbum supernum & $*$ & $*$ & - \\
\hline & lacuna & & & \\
\hline & 30 & & & \\
\hline \multirow[t]{2}{*}{ An.B } & Quomodo fiet istud & $*$ & $*$ & $*$ \\
\hline & Ad horas diei antiphone laudum. Ad primam & & & \\
\hline Reb. & Christe fili Dei vivi & & & \\
\hline V. & Qui natus es de Maria & & & \\
\hline \multirow[t]{2}{*}{ Ve. } & Post partum virgo* & & & \\
\hline & $\begin{array}{l}\text { reliqua Responsoria ut de virginibus. In secundis } \\
\text { vesperis antiphone laudum. psalmi de virginibus. } \\
\text { Super magnificat }\end{array}$ & & & \\
\hline
\end{tabular}




\begin{tabular}{|c|c|c|c|c|}
\hline & Ljubljana & $\mathbf{B A}$ & $\mathbf{S}$ & $\mathbf{R}$ \\
\hline \multirow[t]{4}{*}{ An.M } & Haec est dies quam & $*$ & $*$ & - \\
\hline & lacuna & & & \\
\hline & 31 & & & \\
\hline & $\begin{array}{l}\text { [De Sanctis infra Pascha } \\
\text { In I. Nocturno] }\end{array}$ & & & \\
\hline Re.1 & Pretiosa in conspectu & & & \\
\hline $\mathrm{V}$. & In conspectu omnis & & & \\
\hline Re. 2 & Tristitia vestra alleluia & & & \\
\hline V. & Mundus autem gaudebit & & & \\
\hline Re. 3 & Lux perpetua lucebit & & & \\
\hline \multirow[t]{2}{*}{$\mathrm{V}$. } & Justi autem in perpetuum & & & \\
\hline & In secundo nocturno & & & \\
\hline \multirow[t]{3}{*}{ An.1 } & Sancti tui & & & \\
\hline & lacuna & & & \\
\hline & 32 & & & \\
\hline \multirow[t]{3}{*}{ Re.1 } & De ore prudentis & & & \\
\hline & lacuna & & & \\
\hline & 33 & & & \\
\hline Re. 2 & Isti sunt agni novelli & & & \\
\hline \multirow[t]{2}{*}{ V. } & Ecce praecedet vos & & & \\
\hline & 34 & & & \\
\hline Re.3 & Vidi portam civitatis & & & \\
\hline \multirow[t]{2}{*}{$\mathrm{V}$. } & Vidi sanctam civitatem & & & \\
\hline & In III. nocturno & & & \\
\hline \multirow[t]{4}{*}{ An.1 } & Fulgebunt justi sicut sol & & & \\
\hline & lacuna & & & \\
\hline & 35 & & & \\
\hline & $?$ & & & \\
\hline
\end{tabular}

Antifonal II

\begin{tabular}{|l|l|c|c|c|}
\hline & Ljubljana & BA & S & R \\
\hline & \multicolumn{1}{|c|}{ lacuna } & & & \\
\hline & $\begin{array}{l}\text { [Chrystophori } \\
\text { In II. Nocturno }]\end{array}$ & & - & - \\
\hline Re.2 & Igitur Dagnus rex & $*$ & & \\
\hline V. & Hoc denique spernentes & $*$ & & \\
\hline Re.3 & Beatus Cristophorus dixit ad regem & $*$ & & \\
\hline V. & Ministri vero urgebant & $*$ & & \\
\hline & In tercio nocturno & & & \\
\hline An.1 & Beatus Cristophorus dixit ad regem si & $*$ & & \\
\hline An.2 & Tormenta tua & $*$ & & \\
\hline An.3 & Fera malefica & $*$ & & \\
\hline & 2 & & & \\
\hline Ve. & Magna est gloria ejus* & & & \\
\hline
\end{tabular}




\begin{tabular}{|c|c|c|c|c|}
\hline & Ljubljana & BA & $\mathbf{S}$ & $\mathbf{R}$ \\
\hline Re.1 & Ligatus est ad trabem & $*$ & & \\
\hline V. & Gratia autem divina & $*$ & & \\
\hline Re. 2 & Beatus Cristophorus dixit ad regem disce & $*$ & & \\
\hline \multirow[t]{4}{*}{$\mathrm{V}$. } & Dixit vero sanctus & $*$ & & \\
\hline & lacuna & & & \\
\hline & 3 & & & \\
\hline & $\begin{array}{l}\text { [In Dedicatione Michaelis Archangeli } \\
\text { In I. Nocturno] }\end{array}$ & & & \\
\hline Re.3 & In conspectu gentium & $*$ & $*$ & - \\
\hline \multirow[t]{2}{*}{$\mathrm{V}$. } & Stetit angelus iuxta & $*$ & $*$ & \\
\hline & In II. nocturno & & & \\
\hline An. 1 & Ascendit fumus aromatum & $*$ & $*$ & - \\
\hline Ps. & Domine quis* & & & \\
\hline An. 2 & Michael archangele & $*$ & $*$ & - \\
\hline Ps. & Caeli enarrant* & & & \\
\hline An. 3 & Michael praepositus & $*$ & $*$ & - \\
\hline Ps. & Dominus regit me* & & & \\
\hline Ve. & In conspectu angelorum* & & & \\
\hline Re.1 & In conspectu angelorum & $*$ & $*$ & - \\
\hline V. & Super misericordiam tuam & $*$ & $*$ & \\
\hline \multirow[t]{4}{*}{ Re. 2} & Hic est Michael angelus princeps & $*$ & * & $*$ \\
\hline & lacuna & & & \\
\hline & 4 & & & \\
\hline & [In III. Nocturno] & & & \\
\hline Re.3 & Fidelis sermo et omni & $*$ & * & $*$ \\
\hline \multirow[t]{2}{*}{ V. } & Dum proeliaretur & $*$ & - & - \\
\hline & [Ad Laudes] & & & \\
\hline An. 1 & Dum proeliaretur & $*$ & $*$ & - \\
\hline An. 2 & Dum committeret bellum draco & $*$ & $*$ & $?$ \\
\hline \multirow[t]{4}{*}{ Ps. } & $?$ & & & \\
\hline & lacuna & & & \\
\hline & 5 & & & \\
\hline & $\begin{array}{l}\text { [Omnium Sanctorum } \\
\text { In III. Nocturno] }\end{array}$ & & & \\
\hline Re.3 & Beati pauperes spiritu & $*$ & - & $?$ \\
\hline \multirow[t]{2}{*}{ V. } & Beati misericordes quoniam & $*$ & & \\
\hline & Ad laudes & & & \\
\hline \multirow[t]{4}{*}{ An. 1} & Scimus quoniam diligentibus Deum & $*$ & $*$ & - \\
\hline & lacuna & & & \\
\hline & 6 & & & \\
\hline & $?$ & & & \\
\hline
\end{tabular}


Psalter

\begin{tabular}{|c|c|c|c|c|}
\hline & Ljubljana & BA & BS & $\mathbf{R}$ \\
\hline \multicolumn{5}{|c|}{ lacuna } \\
\hline & 1 & & & \\
\hline & [Feria IV. ad Matutinum] & & & \\
\hline Ps. & Exaudi Deus orationem & $*$ & $*$ & $*$ \\
\hline An.1 & Avertit dominus captivitatem & $*$ & $*$ & $*$ \\
\hline An.2 & Quoniam in te* & $*$ & $*$ & $*$ \\
\hline Ps. & Miserere mei Deus & $*$ & $*$ & $*$ \\
\hline \multicolumn{5}{|c|}{ lacuna } \\
\hline & 2 & & & \\
\hline Ps. & Exaudi Deus deprecationem & $*$ & $*$ & $*$ \\
\hline An. 4 & Da nobis domine auxilium & $*$ & $*$ & $*$ \\
\hline An. 5 & A timore inimici* & $*$ & $*$ & - \\
\hline Ps. & Nonne Deo subjecta & $*$ & $*$ & $*$ \\
\hline \multirow[t]{2}{*}{ Ps. } & Deus Deus meus & - & $*$ & - \\
\hline & 3 & & & \\
\hline Ps. & Exaudi Deus orationem & $*$ & $*$ & $*$ \\
\hline \multirow[t]{3}{*}{ Ps. } & Te decet hymnus Deus & - & $*$ & - \\
\hline & lacuna & & & \\
\hline & 4 & & & \\
\hline An.6 & $?$ & & & \\
\hline Ps. & Iubilate Deo & $*$ & $*$ & $*$ \\
\hline Ps. & Deus misereatur nostri & - & $*$ & - \\
\hline \multirow[t]{2}{*}{ Ps. } & Exurgat Deus et dissipentur & $*$ & $*$ & $*$ \\
\hline & 5 & & & \\
\hline \multirow[t]{4}{*}{ Ps. } & (Exsurgat Deus et dissipentur) & & & \\
\hline & lacuna & & & \\
\hline & 6 & & & \\
\hline & [Feria V. ad Matutinum] & & & \\
\hline \multirow[t]{2}{*}{ Ps. } & Salvum me fac Deus & $*$ & $*$ & * \\
\hline & 7 & & & \\
\hline Ps. & Deus in adiutorium meum & $*$ & $*$ & $*$ \\
\hline An.1 & Domine Deus in adjutorium & * & $*$ & * \\
\hline An.2 & Esto mihi* & $*$ & $*$ & $*$ \\
\hline \multirow[t]{3}{*}{ Ps. } & In te domine & $*$ & $*$ & $*$ \\
\hline & lacuna & & & \\
\hline & 8 & & & \\
\hline An.5 & $?$ & & & \\
\hline Ps. & Voce mea ad dominum & $*$ & $*$ & $*$ \\
\hline \multirow[t]{3}{*}{ Ps. } & Attendite popule & $*$ & $*$ & * \\
\hline & lacuna & & & \\
\hline & 9 & & & \\
\hline \multirow[t]{2}{*}{ Нy. } & $?$ & & & \\
\hline & 10 & & & \\
\hline
\end{tabular}




\begin{tabular}{|c|c|c|c|c|}
\hline & Ljubljana & BA & BS & $\mathbf{R}$ \\
\hline & ymnus in secundis vesperis in quadragesima & & & \\
\hline \multirow[t]{2}{*}{ Hy. } & Dies absoluti praetereunt & $*$ & $?$ & - \\
\hline & ymmus in quadragesima. Ad vesperas & & & \\
\hline \multirow[t]{4}{*}{ Hy. } & Ex more docti mystico & $*$ & $?$ & * \\
\hline & lacuna & & & \\
\hline & 11 & & & \\
\hline & [Dominica I. in quadragesima] & & & \\
\hline \multirow[t]{2}{*}{ Hy. } & Clarum decus jejunii & $*$ & $?$ & - \\
\hline & Ymnus dominica secunda in quadragesima Ad vesperas. & & & \\
\hline \multirow[t]{3}{*}{ Hy. } & Ut nox tenebris & $*$ & $?$ & - \\
\hline & $\begin{array}{l}\text { Predictus ymnus dicatur ad vesperas per totam } \\
\text { hebdomadam. nisi festum occurat. }\end{array}$ & & & \\
\hline & Ymnus Dominica tercia in quadragesima. ad vesperas. & & & \\
\hline \multirow[t]{3}{*}{ Hy. } & Aures ad nostras deitatis & $*$ & $?$ & * \\
\hline & 12 & & & \\
\hline & $\begin{array}{l}P[\text { redictus ymnus dica }] \text { tur omnibus diebus usque ad } \\
\text {.. in quadragesima nisi fes }[\text { tum occurrat. }] \text { Ymnus ad } \\
\text { completorium. Dominica ter }[\text { cia }]\end{array}$ & & & \\
\hline \multirow[t]{2}{*}{ Hy. } & Audi benigne conditor & $*$ & $?$ & $*$ \\
\hline & $\begin{array}{l}\text { Predictus ymnus ... usque ad sabbatum do ... nisi } \\
\text { festum occurrat. [Dominica in] medio quadragesime Ad } \\
\text { vesperas }\end{array}$ & & & \\
\hline \multirow[t]{4}{*}{ Hy. } & Jesu quadragenarie dicator & $*$ & $?$ & - \\
\hline & lacuna & & & \\
\hline & 13 & & & \\
\hline & [Dominica in Passione] & & & \\
\hline \multirow[t]{2}{*}{ Hy. } & Rex Christe factor & $*$ & $?$ & - \\
\hline & ymnus infra pascha & & & \\
\hline \multirow[t]{2}{*}{ Hy. } & Vita sanctorum Deus angelorum & $*$ & $*$ & - \\
\hline & ... completorium infra pascha & & & \\
\hline \multirow[t]{2}{*}{ Нy. } & Ad cenam agni & $*$ & $?$ & * \\
\hline & Ymnus de sancta cruce & & & \\
\hline Hy. & Salve crux sancta & $*$ & $*$ & - \\
\hline
\end{tabular}

\section{Literatura}

Baroffio, Giacomo, in Eun Ju Kim. Historiae sanctorum. Lamezia Terme: A.M.A. Calabria, 1999.

Bratož, Rajko. Krščanstvo v Ogleju in na vzhodnem vplivnem območju oglejske cerkve od začetkov do nastopa verske svobode. Acta Ecclesiastica Sloveniae, 8. Ljubljana: Teološka fakulteta, Filozofska fakulteta, Znanstveni inštitut Filozofske fakultete, 1986. Breviarium Aquileiense. Benetke: Andreas de Torresanis de Asula, 1496.

Breviarium Salzeburgense. Augsburg, 1497. 
Dijk, Stephen J. P. van. Sources of the Modern Roman Liturgy. Zv. 2. Leiden: E. J. Brill, 1963.

Dobszay, László. Salzburg (Pars Temporalis). Corpus Antiphonalium Officii Ecclesiarum Centralis Europae, I/A. Budapest: Institute for Musicology of the Hungarian Academy of Sciences, 1990.

Dreves, Guido Maria, in Clemens Blume, ur. Analecta hymnica. Zv. 45a. Leipzig: O. R. Reisland, 1904.

Fehér, Judith, in László Dobszay. Salzburg (Sanctorale). Corpus Antiphonalium Officii Ecclesiarum Centralis Europae, I/B. Budapest: Institute for Musicology of the Hungarian Academy of Sciences, 2009.

Gilányi, Gabriella, Andrea Kovács in László Dobszay. Aquileia (Temporale). Corpus Antiphonalium Officii Ecclesiarum Centralis Europae, IV/A. Budapest: Institute for Musicology of the Hungarian Academy of Sciences, 2003.

Grabnar, Klemen. »Pričevanja o glasbi v šolskih ustanovah«. V: Zgodovina glasbe na Slovenskem, zv. 1, Glasba na Slovenskem do konca 16. stoletja, uredil Jurij Snoj, 409-426. Ljubljana: Založba ZRC, 2012.

Höfler, Janez. »Gorenjski prispevki k najstarejši glasbeni zgodovini na Slovenskem«. Kronika 14, št. 2 (1966): 91-100.

Kokole, Metoda. »Cerkvena glasba v ljubljanski škofiji«. V: Ljubljanska škofija, uredil France M. Dolinar, 543-560. Ljubljana: Nadškofija Ljubljana, 2011.

Lacoste, Debra, Jan Koláček in Kate Helsen, ur. Cantus. A Database for Latin Ecclesiastical Chant. Splet.

Smolik, Marijan. »Franciscus Josephus Thallmainer, 1698-1768«. Musikološki zbornik 3 (1967): 47-53.

---. »Pontifikal prvih ljubljanskih škofov«. V: Božjo voljo spolnjevati. Jubilejni zbornik ob 75-letnici Alojza Šuštarja, ljubljanskega nadškofa in metropolita, ur. Anton Štrukelj, 623-630. Ljubljana, Celje: Mohorjeva družba Celje, 1995.

Snoj, Jurij. »Petje v srednjeveških obrednih ustanovah na Kranjskem«. De musica disserenda 7, št. 2 (2011): 95-115.

---. Two Aquileian poetic offices. Musicological Studies, LXV/8. Ottawa: The Institute of Mediaeval Music, 2003.

Stäblein, Bruno. Schriftbild der einstimmigen Musik. Musikgeschichte in Bildern, III/4. Leipzig: VEB Deutscher Verlag für Musik Leipzig, 1975.

Ušeničnik, Franc. »Obrednik oglejske cerkve v ljubljanski škofiji«. Bogoslovni vestnik 4 (1924): 1-35, 97-127.

Žnidaršič Golec, Lilijana. Duhovniki kranjskega dela ljubljanske škofije do tridentinskega koncila. Acta Ecclesiastica Sloveniae, 22. Ljubljana: Inštitut za zgodovino Cerkve pri Teološki fakulteti Univerze v Ljubljani, 2000.

---. »Vzroki in okoliščine ustanovitve ljubljanske škofije ter oblikovanje njenega ozemlja.» V: Ljubljanska škofija, ur. France M. Dolinar, 7-26. Ljubljana: Nadškofija Ljubljana, 2011 . 


\section{IN SEARCH OF THE LJUBLJANA CATHEDRAL'S FIRST ANTIPHONER}

\section{Summary}

In 1461, Emperor Frederick III established a new diocese with a chapter of canons in Ljubljana, then the capital of the Habsburg duchy of Carniola. The imperial charter expressly stated that the chapter should sing the liturgy according to the Aquileian rite. In order to follow this decree, the chapter most certainly owned the appropriate liturgical books, but apart from a pontifical whose fragments were discovered some decades ago, these books seemed to have disappeared without a trace.

Among the very numerous fragments of destroyed plainchant manuscripts preserved in Slovenia (and especially in Ljubljana) there are 54 folios written in the same hand. Upon closer examination it turns out that they represent the remnants of a two-volume antiphoner (winter and summer parts) and a psalter (the remaining portions are reconstructed in the appendix to the article). Their script indicates that these manuscripts must have come into being either in the second half of the fifteenth or in the first decades of the sixteenth century. They are written in late Gothic notation (i.e., the Messine neumes of Bruno Stäblein's third epoch), which was widely used in the southern parts of German lands in the later Middle Ages.

A comparison of the preserved contents to the Aquileian rite, the Salzburg rite, and the Roman rite (Haymo of Faversham's Ordo Breviarii) reveals that these three manuscripts followed the Aquileian rite. In this respect it is especially significant that among the preserved offices there is also a versified office for the feast of the Aquileian martyrs Hellarus and Tatianus. As far as can be established, this office appears only in manuscripts from the Patriarchate of Aquileia, outside of which it seems to have been unknown.

From the dates of the archival documents in whose bindings the folios of the three manuscripts survived, it may be conjectured that they fell victim to the bookbinder sometime in the second half of the seventeenth century. This was the period when the Ljubljana diocese was replacing the old Aquileian rite with the Roman rite, a change that led to the destruction of old and obsolete liturgical books. Therefore, it is highly probable that the discovered remnants belonged to the oldest antiphoner and psalter of the cathedral of Ljubljana. 